\title{
The Relationship between Personality Five Factor Theory and the Career Success of Executive Workers in Apparel Sector Organizations in Sabaragamuwa Province Sri Lanka
}

\author{
Dias, SH and Jayasekara, $P$
}

\begin{abstract}
Area of the Study

As a significant determinant of career success of employee, this study is discussing the relationship between Personality Five Factor theory and the Career Success of executive workers in the apparel sector organizations in Sabaragamuwa province Sri Lanka.
\end{abstract}

\section{Problem of the Study}

There is an empirical knowledge gap in the context of the impact of personality five factor theory on the career success of employees in Sri Lanka. therefore, the problem of the study is: Does Five Factor Theory of personality affect to the career success of executives in the apparel sector organization in Sabaragamuwa province.

\section{Method of the study}

The data were collected from a selected sample of 122 executives in the apparel industry in Sabaragamuwa province Sri Lanka by administrating a structured questionnaire, which consisted of 63 questions/ statements with 5 points scale. The data analyses included the univariate and bivariate analyses.

\section{Findings of the Study}

The authors found that some of the factors have strong positive relationship and some have negative relationship and some haven't any relationship with career success of executives in apparel sector organizations in Sabaragamuwa province, Sri Lanka. Extraversion and Conscientiousness have strong positive relationship with career success of the executives and Agreeableness and Neuroticism have negative relationship with the executives of the apparel sector organizations. However, there is no any relationship in Openness to experience with career success of the executives.

\section{Conclusion of the Study}

Future research based on the current theoretical model can investigate the relationship of personality with other work related behaviors and outcomes. The empirical confirmation of this conceptual model is another area of future research. Future research should attempt to replicate these results and develop process models that may explain why conscientiousness and Extraversion have such apparently enduring associations with career success.

Keywords: Personality Five Factors, Career Success, Executives, Apparel Sector Organizations

\section{Introduction}

The personality and career success has been a commonly studied issue in industrial psychology in the past century (Judge \& Ilies 2002; Boudreau \& Bretz 1995; Kilduff \& Day 1994). By understanding the factors of career success employees will be able to have a clearer focus on their career management. Career success can be concern for both individuals 
as well as organizations, because success of worker ultimately contributes to organizational success. Understanding the career success factors is a topic that related to individuals as well as organizations (Judge \& Ilies 2002; Eby, Sorensen \& Feldman 2005; Barrick \& Mount 1991). The majority of the organizations persuade employees to manage their individual careers. These individuals have eager guidance on how to do this successfully. Simultaneously organizations try to recognize the factors that forecast career success in order to successfully select and develop high impending employees. There is a need to examine the factors that influence career success to give the importance of careers to both individuals as well as organizations (Judge, et al. 1995; Hurtz \& Donovan 2002).

Identification of variables that influence career success has received substantial research attention from organizational scholars. Sorenson and Feldman (2005) have classified these factors into four categories; those are human capital, socio-demographic status,organization sponsorship, and individual differences (for example personality). Bell and Staw (1989), judge et al. (1996) Kilduff and Day (1994) have noted that earlier researchers have largely ignored the impact of personality on the career success of employees. Therefore, this study focused on one variable, the influence of individual differences (personality) toward career success. In the personality mainly focus on five factor model.

\section{Literature Review and Hypotheses Development}

In this competitive world organizations face more complex business environments. However, career paths become more and more complex and individuals have to increased responsibility for managing their personal careers. Careers itself necessitates some kind of traits to performed successfully (Gottfredson et al. 1975). Some particular career requires specifics personality traits it should be related to characteristics of job necessities (Caldwell \& Burger, 1998). Career success is highly dependent on the job trait necessities and compatibility of the worker (Judge et al. 1999) and for that reason the study have argued that configuration or synergy of these traits in accordance with these careers (Witt et al. 2002) can produce optimal targets (Roberts \& Robins 2000) and results in day today life (Judge et al. 1999).

Several researchers have discovered the impact of individual traits or behavioural styles on career success (Ferris \& Judge 1991; Judge \& Bretz 1994; Whitely, Doughert \& Dreher 1991). Researchers have begun understand the function of personality in relation to career success as an example (e.g., Howard \& Bray 1994; Judge et al. 1999). There is significant gap in literature because personality has found in dissimilar areas like leadership (e.g., Lord, devader \& Alliger 1986), and job satisfaction (e.g., Judge, et al. 1998). As well as other researchers have noted (Judge et al. 1999; Tharenou 1997; Tokar, Fischer \& Subich 1998) there were few studies that investigated the relationship between personality on career success. However, the relationship of personality factors to the career success of an employee may divergence in nature. Relationship between each variable to the career success may positive, negative or there might be no relationship. Therefore, it seems that there is a gap in the available empirical knowledge in personality and career success, especially in Sri Lanka with regard to the relationship between Personality Five Factor theory and the Career Success 
of executive workers in apparel sector organizations in Sabaragamuwa province Sri Lanka. Therefore, the research problem addressed under this study, what kind of relationship between different personality types of executive workers effect on their career success in apparel sector organizations of Sabaragamuwa province Sri Lanka.

\section{Literature Review}

\section{Openness to Experience}

Openness exhibits an incompatible relationship with career success. Judging from the meta analytic evidence, the association of openness with job satisfaction (Judge et al. 2002). Boudreau et al. (2001) pointed out that openness failed to demonstrate any relationship with intrinsic success, with the significant but little effect on job satisfaction for european executives. Bozionelos in 2004 has found that openness failed to predict subjective career success. Seibert and Kraimer (2001) found that openness has no relation to career satisfaction. They found that openness negatively predicted earnings and was unrelated to number of promotions (Seibert \& Kraimer 2001). Bozionelos (2004) stressed that openness have negative relationship on objective career success. Thus, it appears that openness have inferior level relationship with intrinsic or extrinsic career success. By looking at all previous research findings researcher developed the first hypothesis of this study as follows:

$\mathrm{H}_{1}$ : There is no relationship between the openness to experience and career success of executive workers in apparel industry in Sabaragamuwa province Sri Lanka.

\section{Conscientiousness}

Typically, conscientiousness have positive association with measures of intrinsic career success, Evidence shows that conscientiousness is absolutely associated with job (Judge, Heller \& Mount 2002) and life (DeNeve \& Cooper 1998) satisfaction. Judge, et al. (1999) found that conscientiousness strongly forecasted intrinsic success. On the other hand, several studies have found limited incremental validity in predicting career success with a multivariate design in conscientiousness. Representative findings include non-significant relationships of $\beta^{\wedge}=0.06$ (Seibert \& Kraimer 2001) and $\beta^{\wedge}=0.09$ (Bozionelos 2004) or small but significant effects of $\beta^{\wedge}=-0.05$ among American executives and $\beta^{\wedge}=0.10$ among European executives (Boudreau, et al. 2001). Conscientiousness has theoretical link to extrinsic career success most strongly through the achievement orientation with conscientious persons (McCrae \& Costa 1991). Barrick and Mount (1991) found a small, positive correlation between conscientiousness and salary in five studies. Judge et al. (1999) found that conscientiousness strongly predicted extrinsic success. Conscientiousness also seems to enable persons to obtain promotions into more complex and prestigious jobs. Seibert and Kraimer (2001) found that conscientiousness failed to predict salary and number of promotions. Similarly, Bozionelos (2004) pointed out that conscientiousness failed to forecast self-reported promotion rate. Boudreau et al. (2001) found that conscientiousness has weak relationship with extrinsiccareer success. Across three criteria in two samples, only one coefficient was significant. By looking at all previous research findings researcher developed the second hypothesis in this study as follows: 
$\mathrm{H}_{2}$ : There is a positive relationship between the consciousness and career success of executive workers in apparel industry in Sabaragamuwa province Sri Lanka.

\section{Extraversion}

There are hypothetical arguments and evidence by Watson and Clark (1997) that extroversion is closely and positively link to emotionality. Meta-analytic evidence indicates that extroverts report higher levels of job (Judge et al. 2002) and life (DeNev e\& Cooper 1998) satisfaction. Extroversion positively connected to career satisfaction (Seibert \& Kraimer 2001). As Judge, et al. (1999), extroversion has failed to forecast intrinsic career success. Boudreau et al. (2001) found that both American and European extroverts have higher levels of career satisfaction. Howard and Bray in 1994 have mentioned through their study that dominance characteristics of extroverts (Watson \& Clark 1997) were correlated with managerial advancement. Harrell and Alpert (1989) found that sociability was positively, but not strongly, correlated with the earnings twenty years after the trait was measured. Melamed (1996) found that extroversion have positive correlation with relative wages and managerial level for men but not for women. Hence the third hypothesis of this study was as follows:

$\mathrm{H}^{3}$ : There is a positive relationship between the extraversion and career success of executive workers in apparel industry in Sabaragamuwa province Sri Lanka.

\section{Agreeableness}

Judge, et al. (1999) recorded that agreeableness was unconnected to any measure of intrinsic career success. Seibert and Kraimer (2001) found that agreeableness have negative predictions with career satisfaction. On the other hand, Bozionelos (2004) found that agreeableness positively forecasted subjective career success. Judge, et al. (1999) found that agreeableness have relatively strong negatively prognostic of extrinsic career success. Boudreau, et al. (2001) found that agreeableness negatively predicted all aspects of salary, promotions, and job level for both American and European executives. Seibert and Kraimer (2001) found that agreeableness did not predict salary or promotions. Bozionelos (2004) pointed out that agreeableness negatively predicted objective career success. Thus the fourth hypothesis of this study was as follows:

$\mathrm{H}_{4}$ : There is a negative relationship between the Agreeableness and Career success of executive workers in apparel industry in Sabaragamuwa province Sri Lanka.

\section{Neuroticism}

According to Judge (1999), Costa and McCrae (1992), Furnham and Zacherl (1986), Smith, Organ and Near (1983), Tokar and Subich (1997), Necowitz and Roznowski (1994), Watson and Slack (1993), Brief, Butcher, and Roberson, (1995), Rawls and Rawls (1968), Melamed (1996), Caspi, Elder and Bem (1987), Salgado (1997), Barrick and Mount (1991), Salgado (1997), Howard and Bray (1994), Jones and Whitmore (1995) stressed that there is negative relationship between the neuroticism and the career success of an employee. Thus the fifth hypothesis of this study was as follows:

$\mathrm{H}_{5}$ : There is a negative relationship between the neuroticism and career success of executive workers in apparel industry in Sabaragamuwa province Sri Lanka. 
Relevant schematic diagram is shown in Figure o1. Five factors of personality, Consciousness, Openness to experience, Extraversion, Agreeableness, and Neuroticism are independent variables and Career success is dependent variable.

Figure 01: Conceptual Framework

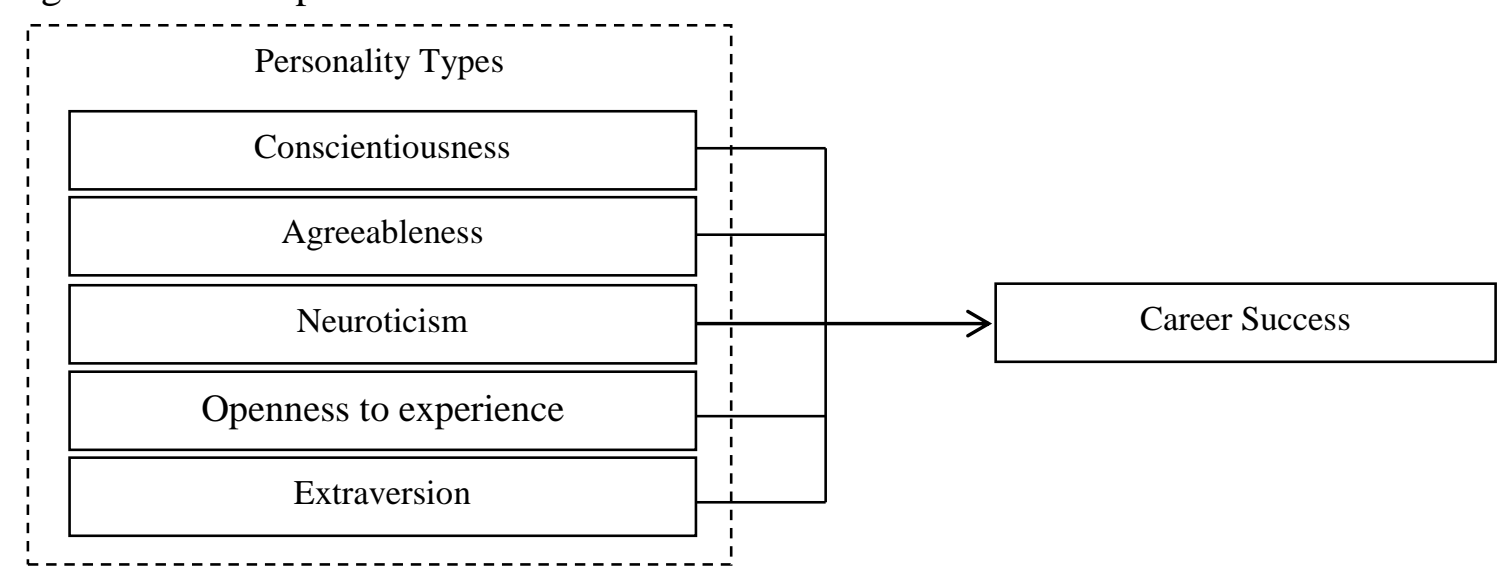

\section{Method}

\section{Sample and Data Collection}

Participants of this study were apparel sector executive workers of Sabaragamuwa province Sri Lanka. As a population of this study, firstly consider about the number of apparel sector organizations in Sabaragamuwa province. The Sabaragamuwa Province contains two districts: Ratnapura and Kegalle. Within these two districts there are around twelve Apparel Export organizations including MAS Holdings, Brandix, Hirdaramani and Maliban etc. Within these organizations there are around 360 executive workers. Information of these organizations was collected from foursquare.com (2015) and Sri Lanka (yellowpg.com. 1990). By considering feasibility of data collection, among these twelve researchers have selected four organizations as a sample Based on convenience.

However, due to the large sizes of populations, researchers may not be able to test every individual in the population, because it is too expensive and time-consuming. In this research, sample is all the executive workers of selected four organization of Sabaragamuwa province Sri Lanka. Sample size is 122 executive workers from selected four organizations.

A questionnaire was used for data collection. Questionnaire method was the only possible method of gathering more reliable information while assuming the anonymity of the respondent. Some of the questions used in this research were well accepted questions and the researcher originally developed others.

\section{Scales and Variables}

The questionnaire for measuring objective career success was originally developed standard questionnaire, by Abele and Spurk in 2009. Monthly salary and hierarchical status was assessed by Abele and Spurk in 2009 applying dichotomous variables. Respondent were 
asked to report the number of promotions they had received over their career. Promotions were defined as any increases in level of their job. Respondent also indicated their current monthly salaries. Objective career success was measured by using 5 questions. Major dimensions of objective career success were salary and hierarchical status.

The questionnaire for measuring subjective career success was also a standard questionnaire, which was developed by Christian Career Center in 2007. It contained ten statements to measure the career satisfaction of executive workers. Respondent were asked to indicate their level of satisfaction with ten statements of their careersranging from1 (Strongly Disagree) to 5 (Strongly Agree) in $\mathrm{n}$ a five point Likert scales. All statements are positive statements.

The questionnaire for measuring personality five factors was also a standard questionnaire, by Goldberg in 1992. It contained 44 statements to measure Extroversion, Agreeableness, Conscientiousness, Neuroticism, and Openness to Experience of executive workers. Based on a series of validity studies using other measures of the big five personality constructs, Goldberg (1992) developed a set of 44 adjective items designed to mark the five higher order factors of the model directly. Questionnaire for measuring personality five factors have a mix of positive and negatively worded statements force respondents to disagree with some statements. Negatively worded questions have included ensuring that the respondents were reading the questions in a thoughtful manner.

\section{Measurement Validation}

Test - re - test method used to examine the external reliability of the instrument. This test was carried out 15 responses (15 executives) from the apparel industry in Sabaragamuwa province in Sri Lanka with two weeks' time interval between two administrations.

Table 1: Test- retest coefficient of survey

\begin{tabular}{|l|l|c|c|}
\hline & & \multicolumn{2}{|c|}{ Test- retest coefficient (cornbach's Alpha) } \\
\hline & Instrument & Pilot Survey & Final Survey \\
\hline 1 & Career Success & 0.958 & 0.948 \\
\hline 2 & Extraversion & 0.937 & 0.922 \\
\hline 3 & Agreeableness & 0.875 & 0.911 \\
\hline 4 & Conscientiousness & 0.896 & 0.894 \\
\hline 5 & Openness to Experience & 0.433 & 0.452 \\
\hline 6 & Neuroticism & 0.964 & 0.968 \\
\hline
\end{tabular}

Test- retest coefficient of survey results have shown in Table 01. Internal consistency was ensured by using Cronbach's $\alpha$ to measure the reliability coefficient ofCareer Success (0.958), Extraversion(0.937), Agreeableness (0.875), Conscientiousness (0.896), Openness to Experience (0.433), and Neuroticism (0.964). Coefficients of the test- retest of the instruments indicate that most of the instrument has a high external reliability but openness to experience reliability is law. Even though openness have less reliability The Five Factor Model need this factor. Because of that researcher decided to continue research with all the factors. 


\section{Data Analysis}

\section{Correlation and Regression Analysis of Openness and Testing Hypothesis 1}

According to the result of the pearson's correlation (0.102), there is no any significance relationship between Openness and Career success of executive workers of apparel sector organizations Sabaragamuwa province Sri Lanka. The pearson correlation between the two variables of executives is 0.102 , it is positive. The found relationship is statistically significant as correlation is significant at 0.05 level ( 2 tailed). But, there is statistical evidence to claim that Openness and Career success are not significantly correlated.

The $\mathrm{b}$ value of the equation, the gradient of the regression, is 0.102 , which is significant at $5 \%$ (significant $=0.000$ ), as indicated by $\mathrm{R}$ Squared, $0.1 \%$ of the variance of career success is explained by Openness with the standardized beta of 0.010 . The F value is 1.114 , which is significant at $5 \%(\mathrm{p}=0.000)$, which suggests that Openness has significantly explained $0.1 \%$ of the variance of career success.

According to the result of Pearson's product movement correlation analysis between personality factor Openness and Career Success of executive workers in apparel sector organizations Sabaragamuwa province Sri Lanka, the correlation coefficient is 0.102 , which is not significant at $5 \%(\mathrm{p}=0.005)$. As per result of simple regression analysis between the two variables the regression coefficient (b) is 0.102 , which is not significant at $5 \%$ (sig. $\mathrm{T}=$ 0.005). Based on the data, there is a no relationship between personality factor Openness and Career Success of executive workers in apparel sector organizations in Sabaragamuwa province Sri Lanka.

\section{Correlation and Regression Analysis of Conscientiousness and Testing Hypothesis 2}

According to the result of the Pearson's correlation (0.953), there is a positive significance relationship between Conscientiousness and Career success of executive workers of apparel sector organizations Sabaragamuwa province Sri Lanka. The pearson correlation between the two variables of executives is 0.953 , it is positive. The found relationship is statistically significant as correlation is significant at 0.05 level ( 2 tailed). Thus, there is statistical evidence to claim that Conscientiousness and Career success are positively correlated.

The $\mathrm{b}$ value of the equation, the gradient of the regression, is 0.953 , which is significant at $1 \%$ (significant $=0.000$ ), as indicated by R Squared, $90.8 \%$ of the variance of career success is explained by Conscientiousness with the standardized beta of 0.908 . The F value is 1052 , which is significant at $1 \%(\mathrm{p}=0.000)$, which suggests that Conscientiousness has significantly explained $90.8 \%$ of the variance of career success.

According to the result of Pearson's product movement correlation analysis between personality factor Conscientiousness and Career Success of executive workers in apparel sector organizations Sabaragamuwa province Sri Lanka, the correlation coefficient is 0.953, which is significant at $5 \%(\mathrm{p}=0.005)$. As per result of simple regression analysis between the two variables the regression coefficient (b) is 0.953 , which is significant at $5 \%$ (sig. $\mathrm{T}=$ 
0.005). Hence the data support the hypothesis that there is a positive relationship between Conscientiousness and Career Success of executive workers in apparel sector organizations in Sabaragamuwa province Sri Lanka.

\section{Correlation and Regression Analysis of Extraversion and Testing Hypothesis 3}

According to the result of the Pearson's correlation (0.951), there is a positive significance relationship between Extraversion and Career success of executive workers of apparel sector organizations Sabaragamuwa province Sri Lanka. The found relationship is statistically significant as correlation is significant at 0.05 levels ( 2 tailed). So, there is statistical evidence to claim that Extraversion and Career success are positively correlated.

The $\mathrm{b}$ value of the equation, the gradient of the regression, is 0.951 , which is significant at $5 \%$ (significant $=0.005$ ), as indicated by R Squared, $90.4 \%$ of the variance of career success is explained by extraversion with the standardized beta of 0.905 . The F value is 1008 , which is significant at $5 \%(\mathrm{p}=0.005)$, which suggests that extraversion has significantly explained $90.4 \%$ of the variance of career success.

The hypothesis testing was carried using the result of person's product movement correlation analysis and the result of regression analysis.

According to the result of Pearson's product movement correlation analysis between personality factor Extraversion and Career Success of executive workers in apparel sector organizations Sabaragamuwa province Sri Lanka, the correlation coefficient is 0.951, which is significant at $5 \%(\mathrm{p}=0.005)$. As per result of simple regression analysis between the two variables the regression coefficient (b) is 0.951 , which is significant at $5 \%$ (sig. $\mathrm{T}=0.005$ ). Hence the data support the hypothesis that there is a positive relationship between Extraversion and Career Success of executive workers in apparel sector organizations in Sabaragamuwa province Sri Lanka

\section{Correlation and Regression Analysis of Agreeableness and Testing Hypothesis 4}

According to the result of the pearson's correlation (-0.931), there is a negative significance relationship between Agreeableness and Career success of executive workers of apparel sector organizations Sabaragamuwa province Sri Lanka. The pearson correlation between the two variables of executives is -0.931 , it is negative. The found relationship is statistically significant at 0.05 level ( 2 tailed). Thus, there is statistical evidence to claim that Agreeableness and Career success are negatively correlated.

The $b$ value of the equation, the gradient of the regression, is -0.931 , which is significant at $1 \%$ (significant $=0.000$ ), as indicated by R Squared, $86.6 \%$ of the variance of career success is explained by Agreeableness with the standardized beta of 0.867 . The F value is 690.34 , which is significant at $1 \%(\mathrm{p}=0.000)$, which suggests that Agreeableness has significantly explained $86.6 \%$ of the variance of career success. 
According to the result of Pearson's product movement correlation analysis between personality factor Agreeableness and Career Success of executive workers in apparel sector organizations Sabaragamuwa province Sri Lanka, the correlation coefficient is -0.931 , which is significant at $5 \%(\mathrm{p}=0.005)$. As per result of simple regression analysis between the two variables the regression coefficient (b) is -0.931 , which is significant at $5 \%$ (sig. $\mathrm{T}=0.005$ ). Hence the data support the hypothesis that there is a negative relationship between personality factor Agreeableness and Career Success of executive workers in apparel sector organizations in Sabaragamuwa province Sri Lanka.

\section{Correlation and Regression Analysis of Neuroticism and Testing Hypothesis 5}

According to the result of the pearson's correlation (-0.942), there is a negative significance relationship between Neuroticism and Career success of executive workers of apparel sector organizations Sabaragamuwa province Sri Lanka. The found relationship is statistically significant because correlation is significant at 0.05 levels ( 2 tailed). Thus, there is statistical evidence to claim that Neuroticism and Career success are negatively correlated.

The $\mathrm{b}$ value of the equation, the gradient of the regression, is -0.942 , which is significant at $1 \%$ (significant $=0.000$ ), as indicated by $\mathrm{R}$ Squared, $88.6 \%$ of the variance of career success is explained by Neuroticism with the standardized beta of 0.887 . The F value is 832.94, which is significant at $1 \%(\mathrm{p}=0.000)$, which suggests that Neuroticism has significantly explained $88.6 \%$ of the variance of career success.

According to the result of Pearson's product movement correlation analysis between personality factor Neuroticism and Career Success of executive workers in apparel sector organizations Sabaragamuwa province Sri Lanka, the correlation coefficient is -0.942., which is significant at $5 \%(\mathrm{p}=0.005)$. As per result of simple regression analysis between the two variables the regression coefficient (b) is- 0.942 , which is significant at $5 \%$ (sig. $\mathrm{T}=0.005$ ).. Hence the data support the hypothesis that there is a negative relationship between personality factor Neuroticism and Career Success of executive workers in apparel sector organizations in Sabaragamuwa province Sri Lanka.

Table 02, 03, 04 shows the Frequency distribution analysis results, correlation results, and regression results respectively. 
Table 02: Frequency distribution analysis for personality five factors

\begin{tabular}{|c|c|c|c|c|c|c|}
\hline & & Extroversion & Agreeableness & Conscientiousness & Openness & Neuroticism \\
\hline \multirow[t]{2}{*}{$\mathrm{N}$} & Valid & 108 & 108 & 108 & 108 & 108 \\
\hline & Missing & 0 & 0 & 0 & 0 & 0 \\
\hline \multicolumn{2}{|c|}{ Mean } & 3.2234 & 2.8210 & 3.9198 & 3.2981 & 2.5475 \\
\hline \multicolumn{2}{|c|}{ Std. Error of Mean } & 0.09003 & 0.06975 & 0.06555 & 0.03415 & 0.10327 \\
\hline \multicolumn{2}{|c|}{ Median } & 3.6250 & 2.6667 & 4.2222 & 3.3000 & 2.1250 \\
\hline \multicolumn{2}{|c|}{ Mode } & 3.75 & 3.33 & 4.22 & 3.50 & 2.12 \\
\hline \multicolumn{2}{|c|}{ Std. Deviation } & 0.93558 & 0.72485 & 0.68119 & 0.35493 & 1.07321 \\
\hline \multicolumn{2}{|c|}{ Variance } & 0.875 & 0.525 & 0.464 & 0.126 & 1.152 \\
\hline \multicolumn{2}{|c|}{ Skewness } & -0.180 & 0196 & -0.280 & 0.050 & 0.428 \\
\hline \multicolumn{2}{|c|}{ Std. Error of Skewness } & 0.233 & 0.233 & 0.233 & 0.233 & 0.233 \\
\hline \multicolumn{2}{|c|}{ Kurtosis } & -1.414 & -1.054 & -1.405 & -0.381 & -0.957 \\
\hline \multicolumn{2}{|c|}{ Std. Error of Kurtosis } & 0.461 & 0.461 & 0.461 & 0.461 & 0.461 \\
\hline \multicolumn{2}{|c|}{ Minimum } & 1.75 & 1.56 & 2.67 & 2.40 & 1.00 \\
\hline \multicolumn{2}{|c|}{ Maximum } & 4.75 & 4.22 & 4.89 & 4.20 & 4.62 \\
\hline
\end{tabular}

Table 03: Correlation results

\begin{tabular}{|l|l|r|r|r|r|r|}
\hline \multirow{2}{*}{$\begin{array}{l}\text { Career } \\
\text { Success }\end{array}$} & $\begin{array}{l}\text { Pearson } \\
\text { Correlation }\end{array}$ & 0.102 & 0.953 & 0.951 & -0.942 & -0.931 \\
\cline { 2 - 7 } & $\begin{array}{l}\text { Sig. } \\
\text { tailed })\end{array}$ & 0.294 & 0.000 & 0.000 & 0.000 & 0.000 \\
\hline
\end{tabular}

Table 04: Regression results

\begin{tabular}{|l|r|r|r|r|r|}
\hline Variables & \multicolumn{1}{|c|}{ Openness } & \multicolumn{1}{c|}{ Conscientiousness } & \multicolumn{1}{c|}{ Extroversion } & \multicolumn{1}{c|}{ Neuroticism } & \multicolumn{1}{c|}{ Agreeableness } \\
\hline Method & \multicolumn{1}{|c|}{ Linear } & \multicolumn{1}{c|}{ Linear } & \multicolumn{1}{c|}{ Linear } & 0.809 \\
\hline R Square & 0.010 & 0.908 & 0.905 & 0.887 & 0.866 \\
\hline $\begin{array}{l}\text { Adjusted } \\
\text { Square }\end{array}$ & 0.001 & 0.908 & 0.904 & 0.886 & 690.337 \\
\hline F & 1.114 & 1052 & 1008 & 832.944 & 0.000 \\
\hline Significance & 0.294 & 0.000 & 0.000 & 0.000 & 5.462 \\
\hline B - Constant & 2.376 & -0.686 & 0.804 & 4.525 & -0.931 \\
\hline b- value & 0.102 & 0.953 & 0.951 & -0.942 & \\
\hline
\end{tabular}

\section{Discussion}

There is no relationship between the openness to experience and career success of executive workers in apparel industry in Sabaragamuwa province Sri Lanka - $H_{1}$

In the Sri Lankan context, Discussion the level of Openness of the respondents in the sample, it was found that they have a favorable level of Openness with the mean value of 3.2981 and standard deviation of 0.35493 . Accordingly it was found that executive workers who have Openness of personality haven't successes their career life. It was found that there is no relationship between Openness and Career success of executive workers in apparel sector organizations in Sabaragamuwa province Sri Lanka. The correlation between these variables was 0.102 , which are significant 0.294 level. This correlation was found week level of 
relationship. According to the result of simple regression analysis, Openness was found to have a positive impact on Career Success with the week level of b value of 0.102 .

There is no evidence that openness positively affect overall work outcomes, it seems to have implications on performance under specific conditions and within specific criteria. Openness is an important quality required for skill acquisition (Oakes et al. 2001) and it has affected overall training proficiency (Barrick \& Mount 1991). It was also seen that those who are high on openness have showed best performance in even unfamiliar environments (Bing \& Lounsbury 2000).

There is a positive relationship between the consciousness and career success of executive workers in apparel industry in Sabaragamuwa province Sri Lanka.

According to the result of simple regression analysis, Conscientiousness was found to have a positive impact on Career Success with the strength of $b$ value of 0.953.

Discussion the level of Conscientiousness of the respondents in the sample, it was found that they have a favorable level of Conscientiousness with the mean value of 3.9198 and standard deviation of 0.68119. Accordingly it was found that executive workers who have Conscientiousness of personality have successes their career life. It was found that there is a positive relationship between Conscientiousness and Career success of executive workers in apparel sector organizations in Sabaragamuwa province Sri Lanka. The correlation between these variables was 0.953 , which are significant 0.000 level. This correlation was found to be strong as it is more than the lower bound of strong correlation $(0.5)$.

Empirical evidence suggests a positive relationship between Conscientiousness and career success (Judge et al. 1999). Barrick and Mount (1991) found a small positive correlation between Conscientiousness and salary in their meta-analysis of research involving variables related to the five factor model. Further, one component of Conscientiousness (Hogan and Ones 1997), were the most Consistent personality predictor of career advancement in the AT\&T studies is ratings of achievement motivation (Howard \& Brayy 1994). Barrick, Mount and Strauss (1993) showed that showed that sales representatives high in Conscientiousness were more likely to set and be committed to sales goals, and goal setting meditated the relationship between Conscientiousness and Career Success.

There is a positive relationship between the extraversion and career success of executive workers in apparel industry in Sabaragamuwa province Sri Lanka.

Discussion the level of Extraversion of the respondents in the sample, it was found that they have a favorable level of Extraversion with the mean value of 3.2234 and standard deviation of 0.93558. Accordingly it was found that executive workers who have extraversion of personality have successes their career life. It was found that there is a positive relationship between Extraversion and Career success of executive workers in apparel sector organizations in Sabaragamuwa province Sri Lanka. The correlation between these variables 
was 0.951 , which are significant at 0.000 level. This correlation was found to be strong as it is more than the lower bound of strong correlation (0.5). According to the result of simple regression analysis, Extraversion was found to have a positive impact on Career Success with the strength of $b$ value of 0.951 .

Empirical evidence has shown that extraversion and several personality dimensions associated with the extraversion are related to career success. In longitudinal research, Caspi, Elder and Bem (1988) found that ratings of shyness in childhood were related to subsequent occupational status attainment. In the longitudinal studies conducted at AT\& T (Howard and Bray 1994), assessment center rating of social skills was related positively to managerial positions. Both shyness (negatively) and social skills (positively) are associated with the extraversion. And Extravert shows high levels of both activity and dominance, traits typically rewarded in employees, exclusively at higher levels and positions of leadership (Dunn, et al. 1995). Extraversion also is related positively to job and life satisfaction (Furnam and Zacherl 1986; McCare and Costa 1991; Waston and Slack 1993), components of career success.

There is a negative relationship between the Agreeableness and Career success of executive workers in apparel industry in Sabaragamuwa province Sri Lanka.

Discussion the level of Agreeableness of the respondents in the sample, it was found that they haven't a favorable level of Agreeableness with the mean value of 2.8210 and standard deviation of 0.72485. Accordingly it was found that executive workers who have Agreeableness of personality have not successes their career life. It was found that there is a negative relationship between Agreeableness and Career success of executive workers in apparel sector organizations in Sabaragamuwa province Sri Lanka. The correlation between these variables was -0.931 which are significant 0.000 level. This correlation was found to be strong as it is more than the lower bound of strong correlation (0.5). According to the result of simple regression analysis, Agreeableness was found to have a negative impact on Career Success with the strength of $b$ value of -0.931 .

Furthermore, Salgado (1997) found agreeableness related positively to job performance in occupations that were not people oriented (professional and skilled laborers) but related negatively to performance in a people oriented occupation (managers). Finally empirical evidence also supports a negative relation between agreeableness and extrinsic career success (Johanson 1997; Judge et al. 1999). Judge, et al. found that their composite measure of agreeableness related negatively to extrinsic success and Johnson found scores on the Califonia Psychological Inventory Likeability scale (Gough 1987) were related negatively to extrinsic career success. Individuals high on agreeableness are characterized as soft hearted, trusting, gullible, and not manipulative and thus would be associated with the negative pole of these personality dimensions. The impression management literature demonstrates the importance of being able to claim credit or shed blame (Crant and Bateman 1993; Mitchell, Green and Wood 1981). 
There is a negative relationship between the neuroticism and career success of executive workers in apparel industry in Sabaragamuwa province Sri Lanka.

Discussion the level of Neuroticism of the respondents in the sample, it was found that they have a favorable level of job satisfaction with the mean value of 2.5475 and standard deviation of 1.07321. Accordingly it was found that executive workers who have Neuroticism of personality have successes their career life. It was found that there is a negative relationship between Neuroticism and Career success of executive workers in apparel sector organizations in Sabaragamuwa province Sri Lanka. The correlation between these variables was -0.942 , which are significant 0.000 level. This correlation was found to be strong as it is more than the lower bound of strong correlation (0.5). According to the result of simple regression analysis, Neuroticism was found to have a negative impact on Career Success with the strength of $b$ value of -0.942 .

Prior literature suggests that Neuroticism may relate to career success through a number of mechanisms. A recent meta-analysis indicated there is a negative relationship in between Neuroticism and job performance (Salgado 1997). The relationship between Neuroticism and Career Success may be complex (Murphy 1989). One should expect Neuroticism to be related negatively to Career outcomes through its association with job performance. Neurotic individuals experience performance decrements at lower activation levels and supply more stress (Spector, Jex \& Chen 1995). In support of activation theory Judge, et al. (1994) found a negative relationship between Neuroticism and their composite measure of career success. Similarly, Turban and Dougherty (1994) found a negative relation between an individual's level of negative affectivity, a component of Neuroticism (Tellegen 1985), and Career Success.

\section{Conclusion}

According to results some of the factors have strong positive relationship and some have negative relationship and some haven't any relationship. Extraversion and Conscientiousness have strong positive relationship, Agreeableness and Neuroticism have negative relationship and researcher couldn't find any relationship in Openness to experience. The findings of this research study shall be important on the theoretical as well as practical scenario. As this research model proves to be an explanatory model of Career Success, the findings of study are important to identify what kind of personality factors should consider when hire executive workers. Future research based on the current theoretical model can investigate the relationship of personality with other work related behaviors and outcomes. The empirical confirmation of this conceptual model is another area of future research. This theoretical framework can be tested empirically so that the validity of the current model is confirmed.

\section{References}

i. Barrick, MR \& Mount, MK 1991, 'The Big five Personality dimensions and Job performance: A meta- analysis', Personnel Psychology, pp.1-26

ii. Bell, NE \&Staw, BM 1989, People as sculptors versus sculpture, The role of personality and personal control in organizations. Eds MB Hall, \&BS Lawrence, The 
handbook of career theory, Cambridge, England, Cambridge University Press, pp 232251

iii. Boudreau, JW, Boswell, WR \& Judge, TA 2001, 'Effects of personality on executive career success in the United States and Europe', Journal of Vocational Behavior, vol. 58, pp.53-81.

iv. Bozionelos, N 2004, 'Mentoring provided: Relation to mentor's career success, personality, and mentoring received', Journal of Vocational Behavior, vol. 64, pp.2446.

v. Mitchell, Terence, R., Kalb \& Laura, S1981,'Effects of outcome knowledge and outcome valence on supervisors' evaluations',Journal of Applied Psychology, Vol 66, No.5, pp. 604-612.

vi. Caldwell, DF\& Burger, JM 1998, 'Personality characteristics of job applicants and success in screening interviews', Personal Psychology,pp.51.

vii. Crant, JM 1993 'The proactive personality scale and objective job performance among real estate agents',Journal of Applied Psychology, Vol. 80, 532-537.

viii. DeNeve, KM \& Cooper, H 1998, 'The happy personality: A meta-analysis of 137 personality traits and subjective well-being', Psychological Bulletin, vol. 124, pp.197-229.

ix. Eby, LT, Sorensen KL \& Feldman DC 2005, 'Predictors of objective and subjective career success: A meta-analysis’, Personnel Psychology, vol. 58 No.2 pp.367 - 409

x. Furnham, A \&Zacherl, M 1986, 'Personality and job satisfaction: Personality and Individual Differences, Personnel Psychology, vol. 1, pp.453-459

xi. Goldberg, LR 1993, 'the structure of phenotypic personality traits: Authors' reactions to the six comments', American Psychologist, vol. 48, pp.1303-1304.

xii. Gottfredson, GD, Holland, JL \&Gottfredson, LS 1975, 'The relation of vocational aspirations and assessments to employments reality', Jurnal of Vocational Behaviour, vol. 7, pp.135- 148.

xiii. Howard, A \& Bray, DW 1994,Predictions of managerial success over time: Lessons from the Management Progress Study,eds KE Clark \& MB Clark, Measures of leadership, West Orange, Leadership Library of America.pp. 113-130

xiv. Hurtz, GM \& Donovan, JJ 2000, 'Personality and Job performance: The Big Five Revisited', Journal of Applied Psychology, pp.869-879

xv. Judge, TA \&Bretz, RD 1994, Politica influence behavior and career success', Jurnal of Management, vol. 20, pp. 43-65

xvi. Judge, TA \&Bretz, RD, Kennedy, DJ \& Bloom, MC 1996, 'People as sculptorsvs sculpture: Test of a dispositional model of career success. Paper presented at the annual meeting of the academy of management

xvii. Judge, TA \&Ilies, R 2002, 'Relationship of personality to performance motivation, A meta-analytic review', Journal of Applied Psychology, vol. 87,No.4,pp. 797 - 807

xviii. Judge, TA, Cable, DM, Boudreau JW \&Bretz RD 1995, 'An Empirical investigation of the predictors of executive career success', Personnel Psychology, vol. 48, pp.485 $-519$ 
xix. Judge, TA, Cable, DM, Boudreau, JW \&Bretz, RDJ 1995, 'An empirical investigation of the predictors of executive career success', Personnel Psychology, vol. 48, No.3, pp.485-519.

xx. Judge, TA, Higgins, C, Thoresen, CJ \&Barrick, MR 1999, 'The Big Five personality traits, general mental ability, and career success across the life span', Personnel Psychology, vol. 52, pp.621-652

xxi. Judge, TA, Higgins, CA, Thoresen, CJ \&Barrick, MR 1999, 'The big five personality traits, general mental ability, and career success across the life span', Personnel Psychology, vol. 52, pp.621-652

xxii. Judge, TA, Locke, EA, Durham, CC \&Kluger, AN 1998, 'Dispositional effects on job and life satisfaction: The role of core evaluations', Journal of Applied Psychology, vol. 83, pp.17-34.

xxiii. Kilduff, M \& Day DV 1994,' Dochamelesons get ahead?The effects of selfmonitoring on managerial careers', Academy of Management Jurnal, vol. 37, pp.1047- 1060.

xxiv. Lord, Robert G, Vader, Christy L, Alliger\& George M 1986,' Journal of Applied Psychology,vol.71, No 3 , pp.402-410.

xxv. Melamed, T 1996, Career success: An assessment of a gender-specific model. Journal of Occupational and Organizational Psychology, vol. 69, pp. 217-242.

xxvi. Ng T, Eby LT, Sorensen KL \& Feldman DC 2005,' Predictors of objective and subjective career success: A meta-analysis, Personnel Psychology, vol. 58,No.2 , pp.367 - 409

xxvii. Roberts BW, Robins RW 2000, 'Broad Dispositions, Broad Aspirations: The Intersection of Personality Traits and Major Life Goals',Personality SocialPsychology Bull, vol. 26, No.10, pp.1284-1296

xxviii. Salgado, JF 1997,'The five-factor model of personality and job performance in the European Community. Journal of Applied Psychology, vol. 82, pp.30-43

xxix. Seibert, SE \&Kraimer, ML 2001, 'The fivefactor model of personality and career success',Journal of Vocational Behavior, vol. 58, pp.1-21.

xxx. Smith, A, Organ, DW \& Near J 1983, 'Organizational citizenship behavior: Its nature and antecedents',Journal of Applied Psychology, vol. 68, No.4, 653-663.

xxxi. Spector, PE\&Brannick, MT 1995, 'The nature and effects of method variance in organizational research', EdsCL, Cooper \& IT, Robertson, International Review of Industrial and Organizational Psychology, Vol. 10, pp. 249-274, Wiley, New York.

xxxii. Tellegen, A 1985 'Structures of mood and personality and their relevance to assessing anxiety, with an emphasis on self-report',Anxiety and theAnxiety Disorderseds AH, Tuma,, J, Mason, Erlbaum, NJ, Hillsdale, pp. 681-706.

xxxiii. Tharenou, P 1997,'Managerial career advancement,Eds CL, Cooper \& IT, Robertson, International Review of Industrial and Organizational Psychology: 39-94. New York: Wiley.

xxxiv. Tokar, DM, Fischer, AR, \&Subich, LM 1998,'Personality and Vocational Behavior: A Selective Review of the Literature', Journal of Vocational Behavior, vol. 53: pp.115-153. 
ISSN: $2012-7227$

xxxv. Tokar, DM. \&Subich, LM 1997,'Relative contributions of congruence and personality dimensions to job satisfaction',Journal of Vocational Behaviour, vol. 50, pp.482-491.

xxxvi. Turban, DB \& Dougherty, TW 1994, 'Role of protégé personality in receipt of mentoring and career success', Academy of Management Journal, Vol.37, pp.688702.

xxxvii. Watson, D\& Slack AK 1993, 'General factors of affective temperament and their relation to job satisfaction over time', Organizational Behaviour, Vol. 54, pp.181-202

xxxviii. Witt, LA, Lisa, A, Burke, Murray, R,Barrick, Michael, \& Mount K 2002,' The interactive effects of Conscientiousness and Agreeableness on job performance,' Applied Psychology, vol. 87, No.1, pp.164-169.

\begin{tabular}{ll}
\hline Dias, SH & $\begin{array}{l}\text { Department of Human Resource Management } \\
\text { University of Sri Jayewardenepura } \\
\text { jhrm@sjp.ac.lk }\end{array}$ \\
\hline Jayasekara, P & Senior Lecturer \\
& Department of Human Resource Management \\
& University of Sri Jayewardenepura \\
& padmijk@sjp.ac.lk \\
& jhrm@sjp.ac.lk \\
\hline
\end{tabular}

